\title{
Insecticidal effect of four plant essential oils against two aphid species under laboratory conditions
}

\author{
Akram Saleh Alghamdi \\ Biology Department, Faculty of Science, Taif University, Taif, Saudi Arabia.
}

\begin{tabular}{|c|c|}
\hline ARTICLE INFO & ABSTRACT \\
\hline $\begin{array}{l}\text { Article history: } \\
\text { Received on: September } 18,2017 \\
\text { Accepted on: October } 25,2017 \\
\text { Available online: February } 17,2018\end{array}$ & $\begin{array}{l}\text { The in vitro aphicidal activity of four medicinal plant essential oils, i.e., Moringa oleifera, Eruca sativa, Raphanus } \\
\text { sativus, and Allium sativum at concentrations of } 1 \%, 2 \% \text {, and } 4 \% \text { on the mortality of rose aphid, Macrosiphum rosae } \\
\text { and black bean aphid, Aphis fabae was evaluated after } 12,24,48 \text {, and } 72 \mathrm{~h} \text { of exposure time. Results revealed that } \\
\text { individual mortality percentages generally increased with increasing of oil concentrations tested at the four exposure }\end{array}$ \\
\hline $\begin{array}{l}\text { Key words: } \\
\text { Macrosiphum rosae, } \\
\text { Aphis fabae, } \\
\text { Essential oils, } \\
\text { Insecticidal activity, } \\
\text { In vitro. }\end{array}$ & $\begin{array}{l}\text { times. Among treatments of the essential oils on } M \text {. rosae mortality, arugula oil significantly gave the highest value } \\
\text { at all concentrations and exposure times that was reached to } 97.5 \% \text {; followed by garlic oil with value of } 80.6 \% \text {; } \\
\text { whereas, treatment of moringa and radish oils gave the lowest values of rose aphid mortality those were amounted to } \\
\text { be } 63.3 \% \text { and } 69.2 \% \text {, respectively. A similar trend was observed in respect to } A \text {. fabae since arugula oil was the best } \\
\text { treatment, but radish oil ranked second, then garlic and moringa oils. On the other hand, garlic oil at concentration of } \\
1 \% \text { gave the lowest mortality of black bean aphid individuals after } 12 \text { and } 24 \text { h of exposure. The study indicates the } \\
\text { possible use of such essential oils against two aphid species. }\end{array}$ \\
\hline
\end{tabular}

\section{INTRODUCTION}

Aphid (Homoptera: Aphididae) has a particular importance as a serious pest of field and glasshouse crops. The aphids are apterous and reproduce parthenogenetically. Aphid populations may increase very rapidly under natural conditions. In spite of the intense control strategies applied so far, aphid species have invaded new areas and have expanded their damage to crops all over the world. The yield losses caused by aphid have been estimated to average about $30-50 \%$ annually [1].

The rose aphid, Macrosiphum rosae is an important pest of rose and many other crops. The adults and nymphs of aphid attack the rose plants and suck cell sap from flowers, tender shoots and buds, ultimately decreasing the market value of rose flowers. Aphid infestation badly affects the flowering capacity of plants, resulting in 20-40\% losses [2].

The black bean aphid, Aphis fabae found throughout the Western Europe, Asia, Africa, and North and South America. It attacks more than 200 species of cultivated and wild plants including sugar beet, bean, potato, sunflower, and tomato. As a result of infestation by the black bean aphid, the leaves of plants became swollen and rolled while the development is ceased. This aphid is considered as the vector for certain plant virus diseases.

\footnotetext{
*Corresponding Author

Akram Saleh Alghamdi,

Biology Department,

Faculty of Science, Taif University,

Taif, Saudi Arabia.

Email: akram9m@hotmail.com
}

To protect plant parts from damage of aphids infestation, growers often apply synthetic chemical insecticides. Although synthetic insecticides usually provide quick and adequate control, for the time being, they are usually expensive and leave long-lasting residues over the exposed surface. Recently, botanical insecticides have long been considered as acceptable alternatives to synthetic chemical insecticides for pest management as they have low persistence in the environment, little mammalian toxicity and resulting in good selectivity, and wide public acceptance $[3,4]$. There have been a large number of plant products, which possess pesticidal properties and have been used successfully for controlling various pests in the field. Botanical products like essential oils have been used to control pests of the stored products as alternative insecticides in various parts of the world [5].

The essential oils with their novel, highly bioactive compounds can be very well used as effective insecticides, and thus should be considered seriously for aphid control [6]. Among botanical extracts, tobacco and neem have been found promising and useful for control of $M$. rosae on different cultivars of Rosa indica [7]. Essential oils of cumin (Cuminum cyminum L.), anise (Pimpinella anisum L.), oregano (Origanum syriacum var. bevanii L.), and eucalyptus (Eucalyptus camaldulensis Dehn.) were effective as fumigants against the cotton aphid (Aphis gossypii Glover) [8]. The bioactivity of essential oil volatiles obtained from Tagetes minuta L. against aphid species, Acyrthosiphon pisum (Harris), M. persicae, and Aulacorthum solani (Kaltenbach) was also recorded [4]. Rapeseed oil significantly reduced damage by black cherry aphid, Myzus cerasi (Fabricius) [9]. Adverse effects of Thymus, Veronica, and Agrimonia essential oils were demonstrated on cabbage 
aphid [10]. In this aspect, this study aimed to assess the aphidical activity of four essential oils against two species of aphid, M. rosae and A. fabae.

\section{MATERIALS AND METHODS}

\subsection{Insects Assayed}

Apterae adults of the rose aphid, M. rosae in Figure 1 were collected from infested rose plants (Rosa damascena); whereas, the black bean aphid, A. fabae in Figure 2 was obtained from hibiscus shrubs (Hibiscus rosa-sinensis), $20 \mathrm{~min}$ before start the experiment.

\subsection{Essential Oils Preparation}

About $100 \%$ naturally essential oils of four medicinal plants, i.e., moringa (Moringa oleifera), arugula (Eruca sativa), radish (Raphanus sativus), and garlic (Allium sativum) were purchased from Al-Hemadi Company, Taif, KSA. Different concentrations of $1 \%, 2 \%$, and $4 \%$ from each essential oil were prepared by dissolving it in Tween- 20 as a negative solvent with a final volume of $100 \mathrm{ml}$ with distilled water.

\subsection{Aphicidal Bioassay}

Whole rose and hibiscus leaves were collected and sprayed with $5 \mathrm{ml}$ of the diluted oil suspensions or control suspensions with either Tween-20 as negative or distilled water as positive. The leaves were dried for 15 min and leaf discs of each plant were punched from the leaves and used in the test. Then, discs were placed upside down in petri dish (10 cm diameter); 10 healthy aphid adults were placed on the treated discs surface. Five replicate batches of aphids (i.e., 50 insects) were used per each concentration of each essential oil. Petri dishes containing aphids were carefully closed and kept at $25 \pm 1{ }^{\circ} \mathrm{C}$ to count died individuals and recorded mortality percentages after 12, 24 , 48 , and $72 \mathrm{~h}$ of application. Mortality was confirmed by touching the aphid with a fine brush. Aphids that appeared no realistic movement were considered as dead. The percentage mortality of the individuals was calculated and recorded. Mortality percentages were transformed to arcsin [11] values just before statistical analysis.

\subsection{Statistical Analysis}

Statistically, the obtained data were subjected to analysis of variance followed by Duncan's multiple ranges to compare means [12].

\section{RESULTS AND DISCUSSION}

The impact of four essential oils at the concentrations of $1 \%, 2 \%$, and $4 \%$ on mortality percentage of $M$. rosae and A. fabae is depicted in Tables 1 and 2, respectively. In general, individual mortality percentages increased with the increase of essential oils concentrations tested at the different exposure duration.

Data in Table 1 and Figure 3 revealed that among treatments of the essential oils on $M$. rosae mortality, arugula oil application significantly ranked first for the highest value at the mean of concentrations and exposure times that was amounted to $97.5 \%$ followed by garlic oil with value of $80.2 \%$. The treatment of moringa oil gave the lowest value of aphid mortality that was amounted to be $63.5 \%$. It is evident that arugula and garlic essential oils at the mean of concentrations tested gave $100 \%$ mortality of aphid individuals after 24,48 , and $72 \mathrm{~h}$ of exposures, whereas, radish and moringa oils gave the same mortality percentage at highest concentration after the same exposure time. At $12 \mathrm{~h}$ of examination, arugula oil used at all concentrations killed $90 \%$

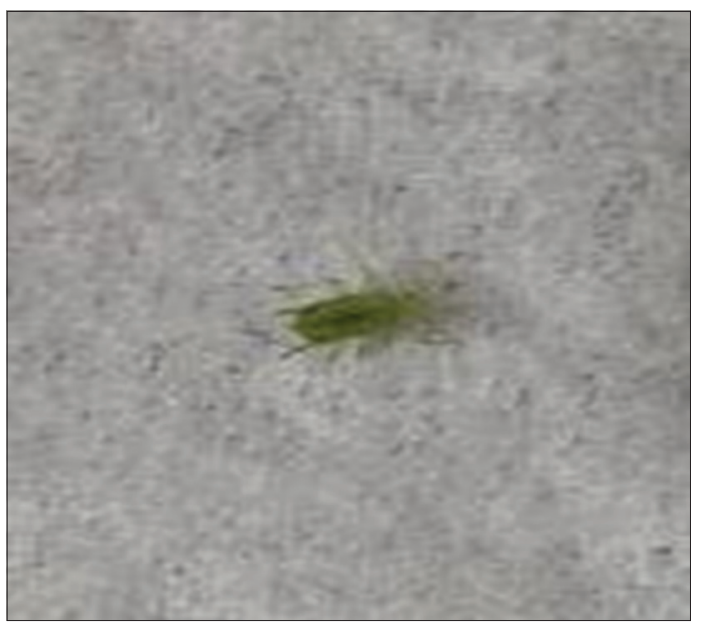

Figure 1: Rose aphid.

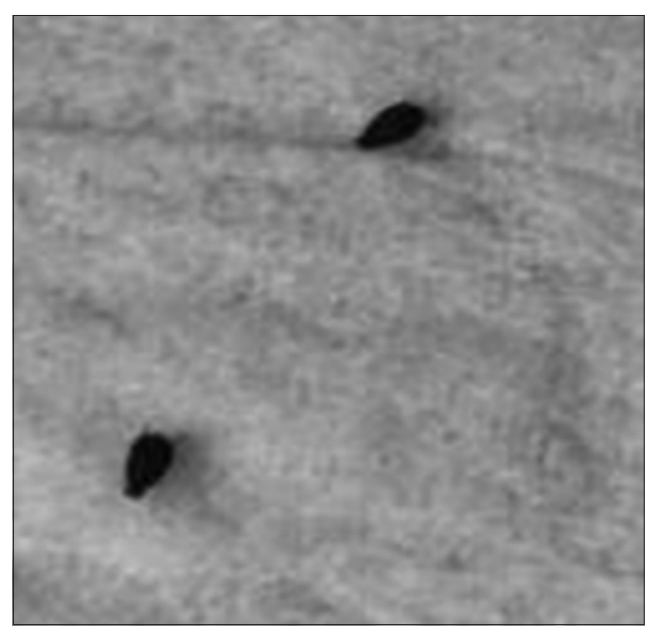

Figure 2: Black bean aphid.

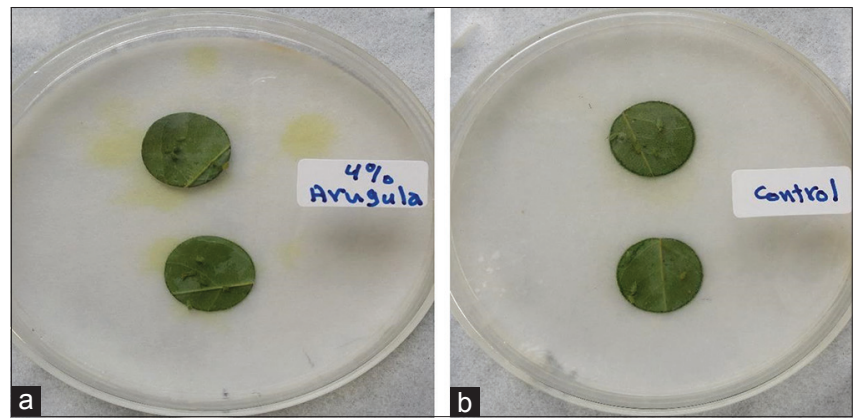

Figure 3: Aphicidal efficacy of arugula (a) against rose aphid in comparison with control (b).

of aphid individuals. On the other hand, $40 \%$ of individuals dead when exposed to moringa oil at concentrations of 1,2 , and $4 \%$ for $12 \mathrm{~h}$. 50 mortality percentage of individuals was obtained from moringa oil at concentrations of $4 \%$ and $1 \%$ after 24 and $72 \mathrm{~h}$ of exposure, respectively; and radish oil at concentrations of $4 \%$ and $2 \%$ after 12 and $24 \mathrm{~h}$ of exposure, respectively (Table 1). These results are in accordance with the aphicidial activity of vapors of essential oils extracted from 12 Mediterranean plants against the pea aphid, A. pisum and green peach aphid, Myzus persicae [3]. 
In general, the plant essential oils and their major components, monoterpenes, are among the most potential botanicals for alternative use to current commercially available insecticides [13]. Essential oils exhibit biological action against a wide spectrum of plant pests and they may act as fumigants, contact insecticides, repellents, and antifeedants or they can affect the growth rate, reproduction, and behavior of insect pests [14-16]. Abies grandis oil $\left(\mathrm{LC}_{50}=0.006 \%\right)$ was significantly the most active contact toxin among 11 essential oils tested against Phyllaphis fagi, whereas, Gaultheria procumbens oil was the most active fumigant against Sitophilus oryzae [17].

Data represented in Table 2 and Figure 4 showed the efficacy of essential oils at three concentrations on $A$. fabae mortality percentages. Likewise, a similar trend was observed concerning bean aphid individuals mortality percentages that were significantly increased as the concentrations and exposure durations increased. Essential oil of arugula gave the highest percentage of individual mortality with value of $94.2 \%$, followed by radish oil $(82.5 \%)$, then garlic and moringa oils with the same value $(72.5 \%)$. The interaction between the three factors tested showed that arugula oil at the concentration of $4 \%$ was

Table 1: Effect of four medicinal plant essential oils on rose aphid mortality

\begin{tabular}{|c|c|c|c|c|c|}
\hline \multirow[t]{2}{*}{ Treatments } & \multirow[t]{2}{*}{ Time (h) } & \multicolumn{3}{|c|}{$\begin{array}{c}\text { Mortality } \%^{\mathrm{a}} \\
\text { Concentration (\%) }\end{array}$} & \multirow[t]{2}{*}{$\begin{array}{c}\text { Treatment } \\
\text { mean }\end{array}$} \\
\hline & & 4 & 2 & 1 & \\
\hline \multirow[t]{4}{*}{ M. oleifera } & 12 & $40 \mathrm{i}$ & $40 \mathrm{i}$ & $40 \mathrm{i}$ & \multirow[t]{4}{*}{$63.5 \mathrm{c}$} \\
\hline & 24 & $50 \mathrm{~h}$ & $56 \mathrm{~h}$ & $40 \mathrm{i}$ & \\
\hline & 48 & $90 \mathrm{bc}$ & $70 \mathrm{fg}$ & $50 \mathrm{~h}$ & \\
\hline & 72 & $100 \mathrm{a}$ & $96 \mathrm{ab}$ & $90 \mathrm{bc}$ & \\
\hline \multirow[t]{4}{*}{ E. sativa } & 12 & $90 \mathrm{bc}$ & $90 \mathrm{bc}$ & $90 \mathrm{bc}$ & \multirow[t]{4}{*}{$97.5 \mathrm{a}$} \\
\hline & 24 & $100 \mathrm{a}$ & $100 \mathrm{a}$ & $100 \mathrm{a}$ & \\
\hline & 48 & $100 \mathrm{a}$ & $100 \mathrm{a}$ & $100 \mathrm{a}$ & \\
\hline & 72 & $100 \mathrm{a}$ & $100 \mathrm{a}$ & $100 \mathrm{a}$ & \\
\hline \multirow[t]{4}{*}{ R. sativus } & 12 & $50 \mathrm{~h}$ & $50 \mathrm{~h}$ & $40 \mathrm{i}$ & \multirow[t]{4}{*}{$69.2 \mathrm{c}$} \\
\hline & 24 & $70 \mathrm{fg}$ & $50 \mathrm{~h}$ & $40 \mathrm{i}$ & \\
\hline & 48 & $90 \mathrm{bc}$ & $80 \mathrm{de}$ & $70 \mathrm{fg}$ & \\
\hline & 72 & $100 \mathrm{a}$ & $100 \mathrm{a}$ & $90 \mathrm{bc}$ & \\
\hline \multirow[t]{4}{*}{ A. sativum } & 12 & 76 ef & $70 \mathrm{fg}$ & $56 \mathrm{~h}$ & \multirow[t]{4}{*}{$80.2 \mathrm{~b}$} \\
\hline & 24 & 76 ef & $70 \mathrm{fg}$ & $66 \mathrm{~g}$ & \\
\hline & 48 & $86 \mathrm{~cd}$ & $86 \mathrm{~cd}$ & $76 \mathrm{ef}$ & \\
\hline & 72 & $100 \mathrm{a}$ & $100 \mathrm{a}$ & $100 \mathrm{a}$ & \\
\hline \multirow[t]{4}{*}{ Tween-20 (Ck1) } & 12 & $0.0 \mathrm{j}$ & & & \multirow[t]{4}{*}{$0.0 \mathrm{~d}$} \\
\hline & 24 & $0.0 \mathrm{j}$ & & & \\
\hline & 48 & $0.0 \mathrm{j}$ & & & \\
\hline & 72 & $0.0 \mathrm{j}$ & & & \\
\hline \multirow{4}{*}{$\begin{array}{l}\text { Distilled } \\
\text { water (Ck2) }\end{array}$} & 12 & $0.0 \mathrm{j}$ & & & \multirow[t]{5}{*}{$0.0 \mathrm{~d}$} \\
\hline & 24 & $0.0 \mathrm{j}$ & & & \\
\hline & 48 & $0.0 \mathrm{j}$ & & & \\
\hline & 72 & $0.0 \mathrm{j}$ & & & \\
\hline \multicolumn{2}{|c|}{ Concentration mean } & $54.9 \mathrm{a}$ & $52.4 \mathrm{a}$ & $47.8 \mathrm{~b}$ & \\
\hline
\end{tabular}

${ }^{a}$ Each figure represents the mean of five replicates. Means in each column followed by the same letter did not differ at $\mathrm{P}>0.05$ according to Duncan's multiple range tests, A. sativum: Allium sativum, $R$. sativus: Raphanus sativus, E. sativa: Eruca sativa, M. oleifera: Moringa oleifera the best treatment for suppressing the aphid individuals with value of $100 \%$ at all times of exposure as well as radish oil done after 24 , 48 , and $72 \mathrm{~h}$ of exposure and those essential oils done at $2 \%$ after 48 and $72 \mathrm{~h}$ with the same value of mortality percentage. It is worth to note that garlic oil at concentration of $1 \%$ gave the lowest mortality
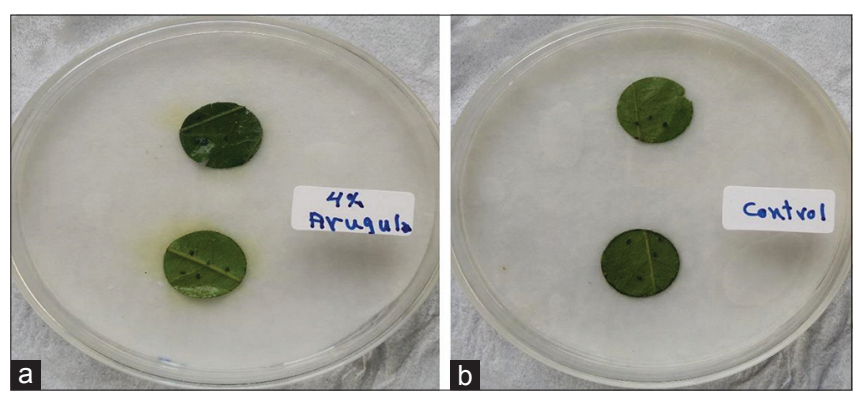

Figure 4: Aphicidal effect of arugula (a) against black bean aphid in comparison with control (b).

Table 2: Effect of four medicinal plant essential oils on black bean aphid mortality

\begin{tabular}{|c|c|c|c|c|c|}
\hline \multirow[t]{2}{*}{ Treatments } & \multirow[t]{2}{*}{ Time (h) } & \multicolumn{3}{|c|}{$\begin{array}{c}\text { Mortality } \% \\
\text { Concentration (\%) }\end{array}$} & \multirow[t]{2}{*}{$\begin{array}{l}\text { Treatment } \\
\text { mean }\end{array}$} \\
\hline & & 4 & 2 & 1 & \\
\hline \multirow[t]{4}{*}{ M. oleifera } & 12 & $70 \mathrm{~d}$ & $70 \mathrm{~d}$ & $60 \mathrm{e}$ & $72.5 \mathrm{c}$ \\
\hline & 24 & $80 \mathrm{c}$ & $70 \mathrm{~d}$ & $60 \mathrm{e}$ & \\
\hline & 48 & $90 \mathrm{~b}$ & $70 \mathrm{~d}$ & $60 \mathrm{e}$ & \\
\hline & 72 & $100 \mathrm{a}$ & $70 \mathrm{~d}$ & $70 \mathrm{~d}$ & \\
\hline \multirow[t]{4}{*}{ E. sativa } & 12 & $100 \mathrm{a}$ & $80 \mathrm{c}$ & $80 \mathrm{c}$ & $94.2 \mathrm{a}$ \\
\hline & 24 & $100 \mathrm{a}$ & $90 \mathrm{~b}$ & $90 \mathrm{~b}$ & \\
\hline & 48 & $100 \mathrm{a}$ & $100 \mathrm{a}$ & $90 \mathrm{~b}$ & \\
\hline & 72 & $100 \mathrm{a}$ & $100 \mathrm{a}$ & $100 \mathrm{a}$ & \\
\hline \multirow[t]{4}{*}{ R. sativus } & 12 & $90 \mathrm{~b}$ & $60 \mathrm{e}$ & $60 \mathrm{e}$ & $82.5 \mathrm{~b}$ \\
\hline & 24 & $100 \mathrm{a}$ & $70 \mathrm{~d}$ & $60 \mathrm{e}$ & \\
\hline & 48 & $100 \mathrm{a}$ & $100 \mathrm{a}$ & $70 \mathrm{~d}$ & \\
\hline & 72 & $100 \mathrm{a}$ & $100 \mathrm{a}$ & $80 \mathrm{c}$ & \\
\hline \multirow[t]{4}{*}{ A. sativum } & 12 & $80 \mathrm{c}$ & $60 \mathrm{e}$ & $40 \mathrm{f}$ & $72.5 \mathrm{c}$ \\
\hline & 24 & $80 \mathrm{c}$ & $60 \mathrm{e}$ & $40 \mathrm{f}$ & \\
\hline & 48 & $90 \mathrm{~b}$ & $80 \mathrm{c}$ & $70 \mathrm{~d}$ & \\
\hline & 72 & $90 \mathrm{~b}$ & $90 \mathrm{~b}$ & $90 \mathrm{~b}$ & \\
\hline \multirow[t]{4}{*}{ Tween-20 (Ck1) } & 12 & $0.0 \mathrm{~g}$ & & & $0.0 \mathrm{~d}$ \\
\hline & 24 & $0.0 \mathrm{~g}$ & & & \\
\hline & 48 & $0.0 \mathrm{~g}$ & & & \\
\hline & 72 & $0.0 \mathrm{~g}$ & & & \\
\hline \multirow{4}{*}{$\begin{array}{l}\text { Distilled } \\
\text { water (Ck2) }\end{array}$} & 12 & $0.0 \mathrm{~g}$ & & & $0.0 \mathrm{~d}$ \\
\hline & 24 & $0.0 \mathrm{~g}$ & & & \\
\hline & 48 & $0.0 \mathrm{~g}$ & & & \\
\hline & 72 & $0.0 \mathrm{~g}$ & & & \\
\hline $\begin{array}{l}\text { Concentration } \\
\text { mean }\end{array}$ & & $61.3 \mathrm{a}$ & $52.9 \mathrm{~b}$ & $46.7 \mathrm{c}$ & \\
\hline
\end{tabular}

${ }^{a}$ Each figure represents the mean of five replicates. Means in each column followed by the same letter did not differ at $\mathrm{P}>0.05$ according to Duncan's multiple range tests, A. sativum: Allium sativum, $R$. sativus: Raphanus sativus, E. sativa: Eruca sativa, M. oleifera: Moringa oleifera 
of individuals after 12 and $24 \mathrm{~h}$ of exposure that was averaged with $40 \%$ (Table 2).

Previous studies have indicated how various essential oil efficient against pests on plants. Most of the studies reported great potentials of the essential oils to control pests, particularly in the greenhouse and in the field $[4,6]$. The insecticidal components of essential oils included linalool [18], carvacrol and thymol [19], eugenol [13], pulegone [20], and $\gamma$-terpinene [21]. The present results are in accordance with those recorded by [22] who evaluated the toxicity of five essential oils, i.e., Zataria multiflora and Nepeta cataria (Lamiaceae), T. minuta and Artemisia sieberi (Asteraceae), and Trachyspermum ammi (Apiaceae) on Brevicoryne brassicae and found that N. cataria oil has great potential to be used in integrated pest management, especially in greenhouses or other closed systems. In laboratory, applications of Juniperus excelsa, Juniperus oxycedrus, Foeniculum vulgare, and Laurus nobilis essential oils significantly reduced the reproduction potential of the cabbage aphid and resulted in higher mortality [23]. A significant insecticidal activity of 53 plant essential oil against the greenhouse whitefly, Trialeurodes vaporariorum was recorded in Korea [24]. The toxic effect of 20 essential oils to the third instar larvae of Spodoptera littoralis (Lepidoptera: Noctuidae) was previously reported [25]. Bioinsecticidal activity of different plant oils and showed that plant oils suppressed the oviposition ability of the Callosobruchus maculatus (Coleoptera: Chrysomelidae) and reduced their damage significantly [26].

\section{CONCLUSION}

In the present study, it was clear that arugula oil application resulted in significant increase in mortality rate. This investigation indicated the possible use of such essential oils at low concentration against two species of aphids tested in vitro. Therefore, future studies are needed to characterize the active compounds in the tested essential oils that have aphicidal properties and possessing complex modes of action before recommend it for IPM program against aphids and other insect pests.

\section{REFERENCES}

1. Ruberson JR. Handbook of Pest Management. New York: Marcel Dekkar Inc.; 1999. p. 842.

2. Jayma LM, Ronald FL. Macrosiphum euphorbiae (Thomas). Hawaii; Department of Entomology Honolulu; 1992. p. 118-21.

3. Digilio MC, Mancini E, Voto E, De Feo V. Insecticidal activity of Mediterranean essential oils. J Plant Interact 2008;3:17-23.

4. Sampson BJ, Tabanca N, Kirimer N, Demirci B, Baser KH, Khan IA, et al. Insecticidal activity of 23 essential oils and their major compounds against adult Lipaphis pseudobrassicae (Davis) (Aphididae: Homoptera). Pest Manag Sci 2005;61:1122-8.

5. Ngamo TS, Ngatanko I, Ngassoum MB, Mapongmestsem PM, Hance T. Persistence of insecticidal activities of crude essential oils of three aromatic plants towards four major stored product insect pests. Afr J Agric Res 2007;2:173-7.

6. Tomova BS, Waterhouse JS, Doberski J. The effect of fractionated Tagetes oil volatiles on Aphid reproduction. Entomol Exp Appl 2005;115:153-9.

7. Quratulain MA, Rafique MK, Ahmad MA, Mahmood R. Management of Macrosiphum rosae on different cultivars of Rosa Indica by using different botanical extracts and detergent solution. Pak Entomol 2015;37:15-20.

8. Tun I, Sahinkaya S. Sensitivity of two greenhouse pest to vapours of essential oils. Entomol Exp Appl 1998;86:183-7.

9. Jaastad G. Late dormant rapeseed oil treatment against black cherry aphid and cherry fruit moth in sweet cherries. J Appl Entomol 2007;131:284-8.

10. Görür G, Abdullah MI, Işı1k M. Insecticidal activity of the Thymus, Veronica and Agrimonia's essential oils against the cabbage aphid, Brevicoryne brassicae. Acta Phytopathol Entomol Hung 2008;43:203-10.

11. Bliss CI. The analysis of field experimental data expressed in percentages. PI Prot Leningr 1937;12:70-2.

12. Duncan DB. Multiple rang and multiple, F-test. Biometrics 1955;11:1-42.

13. Isman $\mathrm{MB}$, Machial $\mathrm{CM}$. Pesticides based on plant essential oils: From traditional practice to commercialization. In: Rai M, Carpinella CM, editors. Naturally Occurring Bioactive Compounds. Amsterdam: Elsevier; 2006. p. 29-44.

14. Isman MB, Wilson JA, Bradbury R. Insecticidal activities of commercial rosemary oils (Rosmarinus officinalis) against larvae of Pseudaletia unipuncta and Trichoplusia $n i$ in relation to their chemical composition. Pharm Biol 2008;46:82-7.

15. Papachristos DP, Stamopoulos DC. Fumigant toxicity of three essential oils on the eggs of Acanthoscelides obtectus (Say) (Coleoptera: Bruchidae). J Stored Prod Res 2004;40:517-25.

16. Petrakis PV, Roussis V, Papadimitriou D, Vagias C, Tsitsimpikou C. The effect of terpenoid extracts from 15 pine species on the feeding behavioural sequence of the late instars of the pine processionary caterpillar Thaumetopoea pityocampa. Behav Processes 2005;69:303-22.

17. Yazdgerdian AR, Akhtar Y, Isman MB. Insecticidal effects of essential oils against woolly beech aphid, Phyllaphis fagi (Hemiptera: Aphididae) and rice weevil, Sitophilus oryzae (Coleoptera: Curculionidae). J Entomol Zool Stud 2015;3:265-71.

18. Ebadollahi A, Mahboubi M. Insecticidal activity of essential oil isolated from Azilia eryngioides (Pau) Hedge Et Lamond against two beetle pests. Chil J Agric Res 2011;71:406-11.

19. Ebadollahi A, Mahboubi M. Insecticidal activity of essential oil isolated from Azilia eryngioides (Pau) Hedge Et Lamond against two beetle pests. Chil J Agric Res 2011;71:406-11.

20. Lee SE, Lee BH, Choi WS, Park BS, Kim JG, Campbell BC, et al. Fumigant toxicity of volatile natural products from Korean spices and medicinal plants towards the rice weevil, Sitophilus oryzae (L). Pest Manag Sci 2001;57:548-53.

21. Moravej GH, Of-Shahraki Z, Azizi-arani M, Yaghmai F. Toxicity fumigant essential oil Bunium persicam Boiss and Elletaria cardamomum Maton. (Zingiberacea) on Tribolium castaneum (Herbst) (Coleoptera: Tenebrionidae). J Plant Prot 2009;23:96-105.

22. Motazedian N, Aleosfoor M, Davoodi A, Bandani AR. Insecticidal activity of five medicinal plant essential oils against the cabbage aphid, Brevicoryne brassicae. J Crop Prot 2014;3:137-46.

23. Mustafa I, Görür G. Aphidicidial activity of seven essential oils against the cabbage aphid, Brevicoryne brassicae L. (Hemiptera: Aphididae). Mun Ent Zool 2009;4:424-31.

24. Choi WI, Lee EH, Choi BR, Park HM, Ahn YJ. Toxicity of plant essential oils to Trialeurodes vaporariorum (Homoptera: Aleyrodidae). J Econ Entomol 2003;96:1479-84.

25. Pavela R. Insecticidal activity of some essential oils against larvae of Spodoptera littoralis. Fitoterapia 2005;76:691-6.

26. Rahman A, Talukder FA. Bioefficacy of some plant derivatives that protect grain against the pulse beetle, Callosobruchus maculatus. J Insect Sci 2006;6:1

\section{How to cite this article:}

Alghamdi AS. Insecticidal effect of four plant essential oils against two aphid species under laboratory conditions. J App Biol Biotech.

2018;6(2):27-30. DOI: 10.7324/JABB.2018.60205 